Article

\title{
Self-Efficacy of Teachers in Initial Training: A Comparison between the Populations of Two Universities
}

\author{
Eduardo Chaves-Barboza ${ }^{1, *(1)}$, Tomás Solá-Martínez ${ }^{2}$, José-Antonio Marín-Marín ${ }^{3}$ (i) \\ and Mariano Sanz-Prieto 4 \\ 1 Department of Educology, National University of Costa Rica, Heredia 86-3000, Costa Rica \\ 2 Facultad de Ciencias de la Educación, University of Granada, 18071 Granada, Spain \\ 3 Department of Didactics and School Organization, University of Granada, 18071 Granada, Spain \\ 4 Department of Didactics and Theory of Education, Universidad Autónoma de Madrid, 28049 Madrid, Spain \\ * Correspondence: echav@una.cr; Tel.: +506-8323-9999
}

Received: 31 May 2019; Accepted: 15 July 2019; Published: 18 July 2019

check for updates

\begin{abstract}
This article carries out a comparison of the self-efficacy of teachers in initial training, between the populations of two universities. A questionnaire with two Likert scales is applied in two samples, 836 subjects from the Universidad Nacional (Costa Rica) and 588 from the Universidad de Granada (Spain). The data is reviewed by means of descriptive and inferential statistics (95\% confidence interval), correlation tests (Kendall $\tau$ correlation coefficient) and variance analysis (Mann-Whitney $\mathrm{U}$ test and Kruskal-Wallis $\mathrm{H}$ test). The results indicate that both populations show high levels of self-efficiency during their initial training, where the self-perceived capacity to pay attention to the explanations and instructions of the teachers excels. Meaningful differences are observed with getting ahead with difficult situations, doing the extra-class tasks and having motivation in the less interesting classes.
\end{abstract}

Keywords: self-efficacy; initial teacher training; university education

\section{Introduction}

The self-efficacy inside the Social Cognitive Theory refers to the self-perception of a person of his own ability to perform specific acts in certain situations, such as achieving a concrete learning with a definite level of difficulty [1-3]. Self-efficacy does not assess whether the person's goals will be achieved or if the acts are finally carried out or not; it is in fact a concept focusing on the person's self-perceived ability to be able to perform them when necessary. The real value of the concept settles on a potent influence in the motivation to assume responsibilities, and about the will to do educational tasks. In fact, a high self-efficacy is needed for a continuous and permanent search of paths to success, avoiding fiasco and frustration, as stated by numerous investigations in this regard [4-10]

The perceptions of a person about their own capacities are directly related with a given time, specific objectives and a concrete environment, therefore, they are not immutable, but dynamic and changing, so that they can get better and develop by increasing the locus of control of the subject about their behaviors and acts, and also increasing the knowledge about their environment and their trustfulness to influence it in a positive way, as shown in research on the subject [11-16]. The development and maintenance of a high self-efficacy in the training field is a way to motivate learning and encourage self-regulation in all the processes, as evidenced by the investigations that relate these variables [17-22]. The subject of self-efficacy faces learning in a critical, systematic and self-regulated way, and proactively assumes the completion of tasks and the accomplishment of their educational goals [23-29]. 
The university context for teacher training offers great opportunities for the self-efficacy investigation, such is the objective of this article, which aims to analyze self-efficacy variables related with doing extra-class tasks, working with classmates, maintaining effort in the face of difficulty and overcoming adverse situations, these variables have been shown to be related to self-efficacy, particularly in teacher training processes in various contexts and levels of education [30-40]. Likewise, the aim is to study the relationships among the self-efficacy variables, and the influence of general variables (degree program, level, sex, age, among others) on them will be analyzed.

\section{Methodology}

As can be seen in the methodological section, this article is of the comparative type with a quantitative methodology.

\subsection{Populations and Samples}

The two populations of the study are, 2682 teachers who are studying their initial training at the Centro de Investigación y Docencia en Educación de la Universidad Nacional de Costa Rica (UNA-CR, Center for Research and Teaching in Education of the National University of Costa Rica) and 5725 teachers who attend the Facultad de Educación de la Universidad de Granada-España (UGR-ES, Faculty of Education of the University of Granada-Spain), arriving at a total number of 8407 subjects. Each population has a direct correspondence with a sample, the first sample consists of 836 subjects from UNA-CR and the second sample of 588 subjects from UGR-ES, meaning a total of 1424 teachers in initial training, to whom the questionnaire has been applied. The sample has been chosen at random by clusters, taking as clusters the groups of teachers in initial training, this sample is representative of the population, with a $5 \%$ sample error for statistical inference.

\subsection{The Questionnaire and Its Variables}

The questionnaire applied to the samples of teachers in initial training had a set of sixteen open questions referring to general variables such as age, sex, age, maximum university graduation obtained, degree program attended and level reached in it, university in which they study, years of work experience and available devices for personal access to Internet. The results obtained in these general variables were extrapolated to the population and were used to relate them to the main variables, as will be clarified in a later section.

The main questions correspond to fourteen self-efficacy variables in teacher training, and they have an ordinal scale of six levels equidistant between two extreme categories (disagreement and agreement). The questionnaire is presented in Figure A1 in the appendix section.

\subsection{Reliability and Validity of the Questionnaire}

It has been determined that the questionnaire has a Cronbach's alpha of 0.881 , which shows that the questionnaire is reliable. Previously, all the items increasing the Cronbach's alpha were eliminated.

On the other hand, by means of a confirmatory factor analysis, it was established that all the items are valid indicators of the self-efficacy dimension. In fact, the items saturate only that dimension.

All the items which were invalid as indicators or did show convergent invalidity (according to the contrast results of the Lagrange Multipliers) were eliminated. Also, those items with saturations not significantly different from cero or those which showed nomological invalidity (according to the Wald Test results) were eliminated.

\subsection{Statistical Tests Performed}

A Relative Frequency analysis was applied to the nominal, ordinals and scalars variables of the questionnaire, complemented with the average and standard deviation calculation. 
Tests were applied for the correlation analysis (Kendall $\tau$ correlation coefficient) among the selfefficacy variables. Together with tests for the variance calculation (Mann-Whitney U test and KruskalWallis $\mathrm{H}$ test) to determinate the existence of significative differences in the self-efficacy variables according to the general variables.

All the statistics tests performed are non-parametric, with a bilateral significance level greater or equal to $95 \%$, and in the case of the variance analysis, they are joined with the calculation of the effect size with a confidence level of $95 \%$.

\section{Results Analysis}

\subsection{Descriptive Analysis of Self-Efficacy in Both Populations}

The relative frequency of the self-efficacy variables are shown in the Table 1, in order to allow the comparison between both university populations, the UNA-CR values are placed in the upper part and the UGR-ES values in the lower part; in each case the arithmetic mean and the standard deviation are calculated.

When adding the relative frequencies of the three top options of the scale (levels 4,5 and 6 ), higher percentages than $75 \%$ are achieved in most variables. In the UGR-ES population, the accumulated percentages of levels 4,5 and 6 are lower than $75 \%$ in the variables "Control the disruptive behavior of my classmates" (56.2\%) and "Motivate myself when classes are uninteresting" (55.1\%), which is also observed in the UNA-CR population, where accumulated percentages of $68.6 \%$ and $67.9 \%$, respectively, are reached, for the three top levels of the variables. In addition, in UGR-ES only an accumulated $69.6 \%$ is reached for levels 4, 5 and 6 in the variable "Prevent behavior problems", while in UNA-CR 77.2\% is reached.

The three self-efficacy variables showing the lowest averages, both for UGR-ES population and UNA-CR population, were "Control the disruptive behavior of my classmates" $\left(\overline{\mathrm{X}}_{\mathrm{UNA}-\mathrm{CR}}=4.12\right.$, $\left.\bar{X}_{\text {UGR-ES }}=3.69\right)$, showing the biggest standard deviation of all of them $\left(\sigma_{\text {UNA-CR }}=1.52, \sigma_{\text {UGR-ES }}=1.24\right)$, "Prevent behavior problems" $\left(\overline{\mathrm{X}}_{\mathrm{UNA}-\mathrm{CR}}=4.5, \overline{\mathrm{X}}_{\mathrm{UGR}-\mathrm{ES}}=4.06\right)$ showing the second highest standard deviation $\left(\sigma_{\text {UNA-CR }}=1.47, \sigma_{\text {UGR-ES }}=1.28\right)$ and "Motivate myself when classes are uninteresting" $\left(\bar{X}_{\text {UNA-CR }}=4.09, \bar{X}_{\text {UGR-ES }}=3.68\right)$ showing the third highest standard deviation $\left(\sigma_{\text {UNA-CR }}=1.42\right.$, $\sigma_{\text {UGR-ES }}=1.32$ ). This indicates that these three variables students of both populations show strong self-efficacy, but that in them can also be observed relatively large variations between students with higher scores and students with lower scores.

In the UNA-CR population, some self-efficacy variables stand out for having averages bigger than 5 and percentages of teachers in training who perceive they have those capacities greater than $90 \%$, these variables are: "Get ahead with the most difficult situations", "Do the exercises correctly", "Pay attention to the teachers' explanations", "Follow the instructions of the teachers correctly", "Achieve learning with little support at home", "Keep working on tasks when they are difficult", "Do my extra-class tasks", "Follow the established rules".

In the case of the UGR-ES population, no variable has an average higher than 5, the three self-efficacy variables with higher averages are the following: Follow the established rules (4.96), "Pay attention to the teachers' explanations" (4.9) and "Follow the instructions of the teachers correctly" (4.9). All of them have in the UGR-ES percentages higher than the $90 \%$ of teachers in training who trust to have those capacities. These three variables have also high averages in the UNA-CR population.

According to the Mann-Whitney test, there are seven self-efficacy variables showing statistically significant differences between the population of the UNA-CR and the population of the UGR-ES, these variables are "Get ahead with the most difficult situations", "Achieve learning with little support at home", "Do my extra-class tasks", "Control the disruptive behavior of my classmates", "Prevent behavior problems", "Remember what I have learned in past lessons" and "Motivate myself when classes are uninteresting". In all cases the teachers in training at UNA-CR show an average significantly greater to those at UGR-ES. 
Table 1. Relative frequency, average and standard deviation of the self-efficacy variables, populations comparation (Universidad Nacional de Costa Rica (UNA-CR)/Universidad de Granada-España $\left.(\mathrm{UGR}-\mathrm{ES})^{*}\right)$.

\begin{tabular}{|c|c|c|c|c|c|c|c|c|}
\hline \multirow{3}{*}{ Self-Efficacy Variables } & \multicolumn{6}{|c|}{ Relative Frequency } & \multirow{3}{*}{$\bar{X}^{(1)}$} & \multirow{3}{*}{$\sigma^{(2)}$} \\
\hline & \multicolumn{3}{|c|}{ Disagree } & \multicolumn{3}{|c|}{ Agree } & & \\
\hline & 1 & 2 & 3 & 4 & 5 & 6 & & \\
\hline \multirow{2}{*}{$\begin{array}{l}\text { Get ahead with the most } \\
\text { difficult situations }\end{array}$} & 1.3 & 1.6 & 4.0 & 15.7 & 29.9 & 47.6 & 5.14 & 1.06 \\
\hline & 0.3 & 1.7 & 10.7 & 23.6 & 41.0 & 22.6 & 4.71 & 1.01 \\
\hline \multirow{2}{*}{ Do the exercises correctly } & 1.0 & 1.5 & 4.4 & 19.2 & 37.7 & 36.4 & 5.00 & 1.01 \\
\hline & 0.2 & 1.2 & 6.1 & 23.0 & 47.0 & 22.5 & 4.83 & 0.90 \\
\hline \multirow{2}{*}{$\begin{array}{l}\text { Pay attention to the } \\
\text { teachers' explanations }\end{array}$} & 0.6 & 1.0 & 4.9 & 17.4 & 37.0 & 39.1 & 5.12 & 1.70 \\
\hline & 0.2 & 1.5 & 6.8 & 22.4 & 37.8 & 31.3 & 4.90 & 0.98 \\
\hline \multirow{2}{*}{$\begin{array}{l}\text { Follow the instructions of the } \\
\text { teachers correctly }\end{array}$} & 0.8 & 0.6 & 2.8 & 13.7 & 34.2 & 47.9 & 5.23 & 0.93 \\
\hline & 0.2 & 1.0 & 7.0 & 20.4 & 43.4 & 27.9 & 4.90 & 0.93 \\
\hline \multirow{2}{*}{$\begin{array}{l}\text { Achieve learning with little } \\
\text { support at home } \\
\text { (3) }\end{array}$} & 1.8 & 2.3 & 6.7 & 12.2 & 30.3 & 46.7 & 5.07 & 1.16 \\
\hline & 1.4 & 2.9 & 11.8 & 22.0 & 37.8 & 24.2 & 4.65 & 1.13 \\
\hline \multirow{2}{*}{$\begin{array}{l}\text { Keep working on tasks when } \\
\text { they are difficult }\end{array}$} & 0.4 & 1.3 & 5.2 & 15.5 & 35.7 & 41.9 & 5.10 & 0.98 \\
\hline & 0.5 & 2.0 & 7.8 & 25.2 & 41.7 & 22.8 & 4.74 & 1.00 \\
\hline \multirow{2}{*}{$\begin{array}{l}\text { Successfully work with } \\
\text { my classmates }\end{array}$} & 2.3 & 1.9 & 7.4 & 21.0 & 32.0 & 35.3 & 4.84 & 1.18 \\
\hline & 0.5 & 2.0 & 8.0 & 21.3 & 39.6 & 28.6 & 4.83 & 1.03 \\
\hline \multirow{2}{*}{$\begin{array}{l}\text { Overcome the adverse influences } \\
\text { of society in my learning }\end{array}$} & 1.6 & 1.8 & 7.3 & 19.4 & 34.1 & 35.8 & 4.90 & 1.12 \\
\hline & 0.0 & 1.5 & 11.2 & 30.6 & 39.5 & 17.2 & 4.60 & 0.95 \\
\hline \multirow{2}{*}{ Do my extra-class tasks ${ }^{(3)}$} & 1.2 & 1.6 & 3.3 & 12.7 & 29.1 & 52.2 & 5.23 & 1.03 \\
\hline & 0.2 & 2.7 & 11.1 & 22.0 & 37.6 & 26.4 & 4.73 & 1.06 \\
\hline \multirow{2}{*}{$\begin{array}{l}\text { Control the disruptive behavior } \\
\text { of my classmates }\end{array}$} & 9.5 & 5.1 & 16.8 & 23.1 & 23.8 & 21.7 & 4.12 & 1.52 \\
\hline & 4.1 & 13.6 & 26.2 & 28.1 & 21.8 & 6.3 & 3.69 & 1.24 \\
\hline \multirow{2}{*}{ Prevent behavior problems ${ }^{(3)}$} & 6.8 & 3.8 & 12.3 & 18.3 & 27.1 & 31.8 & 4.50 & 1.47 \\
\hline & 3.1 & 10.0 & 17.3 & 29.8 & 26.9 & 12.9 & 4.06 & 1.28 \\
\hline \multirow{2}{*}{ Follow the established rules } & 1.6 & 1.9 & 4.0 & 9.8 & 30.1 & 52.5 & 5.23 & 1.08 \\
\hline & 0.3 & 1.5 & 7.2 & 17.6 & 39.1 & 34.3 & 4.96 & 1.00 \\
\hline \multirow{2}{*}{$\begin{array}{l}\text { Remember what I have learned } \\
\text { in past lessons }{ }^{(3)}\end{array}$} & 1.8 & 2.4 & 8.6 & 23.1 & 36.8 & 27.3 & 4.72 & 1.13 \\
\hline & 2.0 & 4.6 & 18.0 & 30.1 & 32.3 & 12.9 & 4.25 & 1.15 \\
\hline \multirow{2}{*}{$\begin{array}{l}\text { Motivate myself when classes } \\
\text { are uninteresting }(3)\end{array}$} & 6.7 & 6.0 & 19.4 & 25.9 & 23.2 & 18.8 & 4.09 & 1.42 \\
\hline & 5.1 & 13.8 & 26.0 & 27.9 & 17.2 & 10.0 & 3.68 & 1.32 \\
\hline
\end{tabular}

$\mathrm{N}=8407\left(\mathrm{~N}_{\text {UNA-CR }}=2682\right.$ and $\left.\mathrm{N}_{\text {UGR-ES }}=5725\right), \mathrm{n}=1424\left(\mathrm{n}_{\mathrm{UNA}-\mathrm{CR}}=836\right.$ and $\left.\mathrm{n}_{\text {UGR-ES }}=588\right)$. The data is inferred to the population with a sampling error $\leq 5 \%$. ${ }^{*}$ In each case, the data in the upper half of the box corresponds to UNA-CR and the data in the lower half corresponds to UGR-ES ${ }^{(1)} \overline{\mathbf{X}}=$ Arithmetic Mean ${ }^{(2)} \sigma=$ Standard Deviation (3) Variable with statistically significant differences between institutions, according to the Mann-Whitney test, $p<0.05$, two-tailed with a $95 \%$ confidence level.

\subsection{Effect of General Variables on the Self-Efficacy of Populations}

Table 2 shows the influence of the general variables on the self-efficacy variables, according to the test (Mann-Whitney U Test or Kruskal-Wallis H Test) carried out and according to the significance level (95\% or $99 \%$ ). In addition, the Effect Size (ES) is indicated in a comparative way, the one corresponding to the population of UNA-CR is placed in the upper part and the one corresponding to the population of UGR-ES is placed in the lower part, with a confidence level of $95 \%$.

In the UGR-ES population the percentage of men is 77\%, in the UNA-CR population the percentages of men and women are more balanced, $51 \%$ are women. As shown in Table 2, only in the UNA-CR population is sex a variable that influences the variable "Do my extra-class tasks" (ES $\mathrm{UNA}_{\mathrm{CR}}=0.113$ ). 
In the same way, only in this university population does the years of work experience influence the variables "Get ahead with the most difficult situations" (ES UNA-CR $=0.117$ ) and "Pay attention to the teachers' explanations" $\left(\mathrm{ES}_{\mathrm{UNA}-\mathrm{CR}}=0.102\right)$, in this population $24 \%$ have teaching working experience, with an average of $1.03 \pm 0.05$ years of experience, with a Standard Deviation (SD) equal to 4.21, while in UGR-ES the population has an average of $0.39 \pm 0.02$ years of experience $(\mathrm{SD}=1.08)$, only $18.9 \%$ of the population has experience as teacher.

The 2682 teachers in training that make up the population of UNA-CR are distributed in twenty degree programs, the most populous are Rural Education I and II Cycles (315), Orientation (270), Teaching Mathematics (238), Teaching Social Studies (191) and Special Education (177). In the case of UGR-ES, its population is distributed in nine degree programs, the most populous are Degree in Primary Education (2181), Degree in Early Childhood Education (1333), Secondary Education Teaching Staff (710) and Degree in Social Education (613).

The "Degree program", as a general variable, influenced the self-efficacy variables of the teachers in training, in both university populations it influenced "Prevent behavior problems" $\left(\mathrm{ES}_{\mathrm{UNA}-\mathrm{CR}}=0.113\right.$ and ES $\left.S_{U G R-E S}=0.135\right)$, "Successfully work with my classmates" $\left(E_{\text {UNA-CR }}=0.188\right.$ and $\left.E S_{U G R-E S}=0.116\right)$ and "Follow the instructions of the teachers correctly" (ES UNA-CR $=0.136$ and ES UGR-ES $=0.105)$. Only in the UNA-CR population did it influence "Get ahead with the most difficult situations" (ES UNA-CR $=0.108)$, "Keep working on tasks when they are difficult" $\left(\mathrm{ES}_{\mathrm{UNA}-\mathrm{CR}}=0.138\right)$, "Motivate myself when classes are uninteresting" (ES $\left.\mathrm{UNA}_{\mathrm{C}-\mathrm{CR}}=0.11\right)$, "Overcome the adverse influences of society in my learning" (ES UNA-CR $=0.147$ ) and "Do my extra-class tasks" $\left(E S_{U N A-C R}=0.182\right)$. On the other hand, only in the UGR-ES population does this variable affect the self-efficacy variable "Control the disruptive behavior of my classmates".

Table 2. Effect of general variables on the self-efficacy variables, populations comparation (UNACR/UGR-ES *).

\begin{tabular}{|c|c|c|}
\hline \multicolumn{3}{|c|}{ Results of the Analysis of Variance Test with Confidence Intervals for the Effect Size } \\
\hline Independent Variable (General) & Effect Size (ES) 95\% & Dependent Variable (Main) \\
\hline Sex & $\begin{array}{c}0.113 \pm 0.057^{(b)} \\
-\end{array}$ & Do my extra-class tasks \\
\hline \multirow{9}{*}{ Degree program } & $\begin{array}{l}\mathbf{0 . 1 0 8} \pm \mathbf{0 . 0 0 5 4} \text { (d) }^{\text {(d) }} \\
0.091 \pm 0.0455^{\text {(c) }}\end{array}$ & $\begin{array}{l}\text { Get ahead with the most } \\
\text { difficult situations }\end{array}$ \\
\hline & $\begin{array}{c}0.136 \pm 0.068^{(d)} \\
0.105 \pm 0.0525^{(d)}\end{array}$ & $\begin{array}{l}\text { Follow the instructions of } \\
\text { the teachers correctly }\end{array}$ \\
\hline & $\begin{array}{l}\mathbf{0 . 1 3 8} \pm \mathbf{0 . 0 6 9} \mathbf{( d )}^{(\mathrm{d})} \\
0.046 \pm 0.023^{(\mathrm{c})}\end{array}$ & $\begin{array}{l}\text { Keep working on tasks when } \\
\text { they are difficult }\end{array}$ \\
\hline & $\begin{aligned} \mathbf{0 . 1 1} & \pm \mathbf{0 . 0 5 5} \\
0.087 & \pm 0.0435^{(\mathrm{d})}\end{aligned}$ & $\begin{array}{l}\text { Motivate myself when classes } \\
\text { are uninteresting }\end{array}$ \\
\hline & $\begin{array}{l}0.188 \pm 0.094^{(d)} \\
0.116 \pm 0.058^{(d)}\end{array}$ & $\begin{array}{l}\text { Successfully work with } \\
\text { my classmates }\end{array}$ \\
\hline & $\begin{array}{l}\mathbf{0 . 1 4 7} \pm \mathbf{0 . 0 7 3 5} 5^{\text {(d) }} \\
0.081 \pm 0.0405^{(\mathrm{c})}\end{array}$ & $\begin{array}{l}\text { Overcome the adverse influences } \\
\text { of society in my learning }\end{array}$ \\
\hline & $\begin{array}{l}\mathbf{0 . 1 8 2} \pm \mathbf{0 . 0 9 1}{ }^{\text {(d) }} \\
0.037 \pm 0.0185^{(\mathrm{c})}\end{array}$ & Do my extra-class tasks \\
\hline & $\begin{array}{l}0.093 \pm 0.0465^{(\mathrm{c})} \\
0.106 \pm 0.053^{(\mathrm{c})}\end{array}$ & $\begin{array}{l}\text { Control the disruptive behavior } \\
\text { of my classmates }\end{array}$ \\
\hline & $\begin{array}{l}0.113 \pm 0.0565^{(d)} \\
0.135 \pm 0.0675^{(d)}\end{array}$ & Prevent behavior problems \\
\hline
\end{tabular}


Table 2. Cont.

\begin{tabular}{|c|c|c|}
\hline \multicolumn{3}{|c|}{ Results of the Analysis of Variance Test with Confidence Intervals for the Effect Size } \\
\hline Independent Variable (General) & Effect Size (ES) 95\% & Dependent Variable (Main) \\
\hline \multirow{5}{*}{$\begin{array}{l}\text { Level reached in the } \\
\text { degree program }\end{array}$} & $0.108 \pm 0.054(d)$ & $\begin{array}{l}\text { Get ahead with the most } \\
\text { difficult situations }\end{array}$ \\
\hline & $0.125 \pm 0.0625^{(d)}$ & Do the exercises correctly \\
\hline & $0.139 \pm 0.0695^{(d)}$ & $\begin{array}{l}\text { Remember what I have learned } \\
\text { in past lessons }\end{array}$ \\
\hline & $0.12 \pm 0.06^{(d)}$ & $\begin{array}{l}\text { Overcome the adverse influences } \\
\text { of society in my learning }\end{array}$ \\
\hline & $0.212 \pm 0.106^{(d)}$ & Do my extra-class tasks \\
\hline \multirow{2}{*}{ Working experience years } & 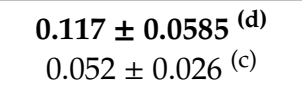 & $\begin{array}{l}\text { Get ahead with the most } \\
\text { difficult situations }\end{array}$ \\
\hline & $\begin{array}{c}\mathbf{0 . 1 0 2} \pm \mathbf{0 . 0 5 1 ^ { ( \mathrm { d } ) }} \\
0.01 \pm 0.005^{(\mathrm{c})}\end{array}$ & $\begin{array}{l}\text { Pay attention to the } \\
\text { teachers' explanations }\end{array}$ \\
\hline \multirow{4}{*}{$\begin{array}{l}\text { Another degree program } \\
\text { has been completed }\end{array}$} & 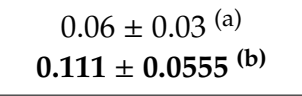 & Do the exercises correctly \\
\hline & $\begin{array}{l}0.097 \pm 0.0485^{(a)} \\
\mathbf{0 . 1 1 1} \pm \mathbf{0 . 0 5 5 5}\end{array}$ & $\begin{array}{l}\text { Pay attention to the } \\
\text { teachers' explanations }\end{array}$ \\
\hline & $0.134 \pm 0.067^{(b)}$ & Do my extra-class tasks \\
\hline & $0.103 \pm 0.0515^{(b)}$ & $\begin{array}{l}\text { Control the disruptive behavior } \\
\text { of my classmates }\end{array}$ \\
\hline Studied at a different University & 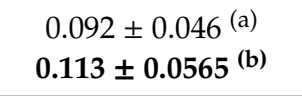 & Do the exercises correctly \\
\hline \multirow{3}{*}{$\begin{array}{l}\text { Maximum university } \\
\text { graduation obtained }\end{array}$} & $0.128 \pm 0.064^{(d)}$ & Do the exercises correctly \\
\hline & $\begin{array}{c}0.041 \pm 0.0205^{(\mathrm{c})} \\
\mathbf{0 . 1 1 4} \pm \mathbf{0 . 0 5 7}\end{array}$ & $\begin{array}{l}\text { Pay attention to the } \\
\text { teachers' explanations }\end{array}$ \\
\hline & 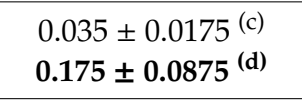 & Do my extra-class tasks \\
\hline \multirow{2}{*}{$\begin{array}{l}\text { Availability of a laptop to } \\
\text { access the Internet }\end{array}$} & $0.111 \pm 0.0555^{(b)}$ & $\begin{array}{c}\text { Keep working on tasks when } \\
\text { they are difficult }\end{array}$ \\
\hline & 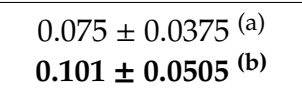 & $\begin{array}{l}\text { Remember what I have learned } \\
\text { in past lessons }\end{array}$ \\
\hline $\begin{array}{l}\text { Availability of a tablet to } \\
\text { access the Internet }\end{array}$ & $\begin{array}{l}0.135 \pm 0.066^{(b)} \\
0.102 \pm 0.051^{(b)}\end{array}$ & $\begin{array}{l}\text { Successfully work with } \\
\text { my classmates }\end{array}$ \\
\hline \multirow{2}{*}{$\begin{array}{l}\text { Availability of a tablet to } \\
\text { access the Internet }\end{array}$} & $0.101 \pm 0.0505^{(b)}$ & \multirow{2}{*}{$\begin{array}{l}\text { Overcome the adverse influences } \\
\text { of society in my learning }\end{array}$} \\
\hline & $0.036 \pm 0.018^{(\mathrm{a})}$ & \\
\hline
\end{tabular}

$\mathrm{N}=8407\left(\mathrm{~N}_{\text {UNA-CR }}=2682\right.$ and $\left.\mathrm{N}_{\text {UGR-ES }}=5725\right), \mathrm{n}=1424\left(\mathrm{n}_{\mathrm{UNA}-\mathrm{CR}}=836\right.$ and $\left.\mathrm{n}_{\mathrm{UGR}-\mathrm{ES}}=588\right) .{ }^{*}$ In each case, the data in the upper half of the box corresponds to UNA-CR and the data in the lower half corresponds to UGR-ES. (a) $p<0.05$ according to Mann-Whitney $\mathrm{U}$ test, this implies a margin of error of less than $5 \%$ (b) $p<0.01$ according to Mann-Whitney U test, this implies a margin of error of less than $1 \%{ }^{\text {(c) }} p<0.05$ according to Kruskal-Wallis H test, this implies a margin of error of less than $5 \%{ }^{(\mathrm{d})} p<0.01$ according to Kruskal-Wallis $\mathrm{H}$ test, this implies a margin of error of less than $1 \%$. In all cases tests were two-tailed with a $95 \%$ confidence level.

The general variable "Level reached in the degree program" only influences learning self-efficacy variables in the UGR-ES population of teachers in training, this variable affects "Get ahead with the most 
difficult situations" $\left(E_{\mathrm{UGR}} \mathrm{ES}=0.108\right)$, "Do the exercises correctly" $\left(\mathrm{ES}_{\mathrm{UGR}} \mathrm{ES}=0.125\right)$, "Remember what I have learned in past lessons" (ES UGR-ES $=0.139)$, "Overcome the adverse influences of society in my learning" (ES UGR-ES $=0.12)$ and "Do my extra-class tasks" $\left(E_{\text {UGR-ES }}=0.212\right)$.

It should be noted that in the UNA-CR population of teachers in training $30.6 \%$ are at the first level, $27.5 \%$ at the second, $12.5 \%$ at the third, $22.3 \%$ at the fourth and $15.1 \%$ at postgraduate level. In the case of the UGR-ES population, only $8.4 \%$ are at postgraduate level, $38 \%$ are at the third level, $35.4 \%$ are at the second level and $18.2 \%$ at the first level.

In the UGR-ES population, $17.9 \%$ have studied at another university, and $24 \%$ have completed another degree program. In the case of UNA-CR, $19.5 \%$ of the population have completed another degree program and just $21 \%$ have studied at another university. In the UGR-ES population $2.7 \%$ have a doctorate ( $2.7 \%$ have postgraduate) while in the UNA-CR population, just $0.1 \%$ have this degree $(6.74 \%$ have postgraduate). Regarding the other degrees, in the populations of UNA-CR and UGR-ES, $1.8 \%$ and $1.5 \%$ have a bachelor's degree and $12.2 \%$ and $14.8 \%$ have a lower degree, respectively. The vast majority of both populations do not have a university degree (UNA-CR $=79.3 \%$, UGR-ES $=79.4 \%$ ).

In the UGR-ES population, the self-efficacy variable "Do the exercises correctly" is influenced by "Another degree program has been completed" $\left(E_{\text {UGR-ES }}=0.111\right)$, the "Maximum university graduation obtained" (ES UGR-ES $=0.128)$ and having "Studied at a different University" $\left(E_{\text {UGR-ES }}=0.113\right)$, the latter has an effect on the self-efficacy variable "Control the disruptive behavior of my classmates". Only in the UGR-ES population is the variable "Pay attention to the teachers" explanations" affected by "Another degree program has been completed" $\left(\mathrm{ES}_{\mathrm{UGR}-\mathrm{ES}}=0.111\right)$ and the "Maximum university graduation obtained" (ES UGR-ES $=0.114)$; also, only in the UGR-ES population is the variable "Do my extra-class tasks" affected by these same two general variables with $\mathrm{ES}_{\mathrm{UGR}-\mathrm{ES}}=0.134$ and $\mathrm{ES}_{\mathrm{UGR}} \mathrm{ES}=0.175$, respectively.

The UGR-ES population accesses the Internet using a diversity of devices, the main ones are Smartphones (99.83\% of the population), laptops (97.96\% of the population), desktop computers (52.04\% of the population) and tablets ( $46.43 \%$ of the population). These devices are also the ones mainly used by the UNA-CR population: Smartphones (95.17\%), laptops (82.48\%), desktop computers $(48.14 \%)$ and tablets $(29.74 \%)$. The "Availability of a laptop to access the Internet", as a general variable, influences the variable "Successfully work with my classmates" in both populations (ES UNA-CR $=0.135$ and ES $S_{U G R-E S}=0.102$ ), and only in the UGR-ES population does this general variable influence the "Keep working on tasks when they are difficult" (ES UGR-ES $=0.111$ ) and "Remember what I have learned in past lessons" (ES UGR-ES $=0.101)$. In the case of the UNA-CR population, the "Availability of a laptop to access the Internet" is a variable that has an impact on the self-efficacy variable "Overcome the adverse influences of society in my learning" $\left(\mathrm{ES}_{\mathrm{UNA}-\mathrm{CR}}=0.101\right)$.

\subsection{Relationship between the Populations' Self-Efficacy Variables}

Table 3 shows the self-efficacy variables correlations of the two populations of teachers in initial training, the UNA-CR coefficients are placed in the upper position and the UGR-ES coefficients in the lower one.

As can be seen in the matrix, for both university populations the variables "Get ahead with the most difficult situations" and "Do the exercises correctly "are strongly correlated ( $\tau \geq 0.5)$, in turn, the variable "Pay attention to the teachers" explanations" is strongly correlated with the variables "Do the exercises correctly" and "Follow the instructions of the teachers correctly" $(\tau \geq 0.5)$. Also, the variables "Control the disruptive behavior of my classmates" and "Prevent behavior problems" are potently related $(\tau \geq 0.5)$ for both university populations.

On the other hand, for both populations of teachers in training, the variable "Do my extra-class tasks" has a median relation $(0.5>\tau \geq 0.4)$ with the variable "Overcome the adverse influences of society in my learning", and it has a strong relationship $(\tau \geq 0.5)$ with "Follow the established rules" only for UNA-CR. For both populations the variable "Keep working on tasks when they are difficult" is moderately related $(0.5>\tau \geq 0.4)$ with the variables "Get ahead with the most difficult situations", "Do the exercises correctly ", "Achieve learning with little support at home" and "Follow 
the instructions of the teachers correctly". This last variable, in turn, is moderately related $(0.5>\tau \geq 0.4)$ with the variable "Follow the established rules", for both UGR-ES and UNA-CR; and is moderately related to the variable "Keep working on tasks when they are difficult" only for UGR-ES.

Only for UNA-CR are the variables "Get ahead with the most difficult situations", "Pay attention to the teachers' explanations" and "Overcome the adverse influences of society in my learning" moderately related to each other, this last variable, is moderately related to the variables "Do the exercises correctly ", "Successfully work with my classmates", "Follow the instructions of the teachers correctly" and "Keep working on tasks when they are difficult".

Also, for UNA-CR, the variables "Achieve learning with little support at home", "Get ahead with the most difficult situations" and "Follow the instructions of the teachers correctly" are moderately related to each other. This last variable is moderately related to "Do my extra-class tasks", which in turn has a median relation with "Keep working on tasks when they are difficult", only for UNA-CR.

Table 3. Correlation between self-efficacy variables, population comparison (UNA-CR/UGR-ES *).

\begin{tabular}{|c|c|c|c|c|c|c|c|c|c|c|c|}
\hline \multirow{2}{*}{\multicolumn{2}{|c|}{ Variables }} & \multicolumn{10}{|c|}{ Kendal $\tau$ Coefficient } \\
\hline & & 1 & 2 & 3 & 4 & 5 & 6 & 7 & 8 & 9 & 10 \\
\hline 1 & $\begin{array}{l}\text { Get ahead with the most } \\
\text { difficult situations }\end{array}$ & & & & & & & & & & \\
\hline 2 & Do the exercises correctly & $\begin{array}{l}0.579 \\
0.583\end{array}$ & & & & & & & & & \\
\hline 3 & $\begin{array}{l}\text { Pay attention to the } \\
\text { teachers' explanations }\end{array}$ & $\begin{array}{l}0.426 \\
0.379\end{array}$ & $\begin{array}{l}0.552 \\
0.498\end{array}$ & & & & & & & & \\
\hline 4 & $\begin{array}{c}\text { Follow the instructions of } \\
\text { the teachers correctly }\end{array}$ & $\begin{array}{l}0.434 \\
0.369\end{array}$ & $\begin{array}{l}0.474 \\
0.471\end{array}$ & $\begin{array}{l}0.558 \\
0.633\end{array}$ & & & & & & & \\
\hline 5 & $\begin{array}{c}\text { Achieve learning with little } \\
\text { support at home }\end{array}$ & $\begin{array}{l}0.414 \\
0.383\end{array}$ & $\begin{array}{l}0.357 \\
0.38 \\
\end{array}$ & $\begin{array}{l}0.338 \\
0.335\end{array}$ & $\begin{array}{l}0.428 \\
0.386\end{array}$ & & & & & & \\
\hline 6 & $\begin{array}{l}\text { Keep working on tasks when } \\
\text { they are difficult }\end{array}$ & $\begin{array}{l}0.448 \\
0.457\end{array}$ & $\begin{array}{l}0.408 \\
0.431\end{array}$ & $\begin{array}{l}0.384 \\
0.379\end{array}$ & $\begin{array}{l}0.381 \\
0.402\end{array}$ & $\begin{array}{l}0.477 \\
0.478\end{array}$ & & & & & \\
\hline 7 & $\begin{array}{l}\text { Successfully work with } \\
\text { my classmates }\end{array}$ & $\begin{array}{l}0.341 \\
0.312\end{array}$ & $\begin{array}{l}0.275 \\
0.301\end{array}$ & $\begin{array}{l}0.273 \\
0.373\end{array}$ & $\begin{array}{l}0.374 \\
0.35\end{array}$ & $\begin{array}{l}0.267 \\
0.258\end{array}$ & $\begin{array}{l}0.323 \\
0.322\end{array}$ & & & & \\
\hline 8 & $\begin{array}{l}\text { Overcome the adverse influences } \\
\text { of society in my learning }\end{array}$ & $\begin{array}{l}0.417 \\
0.374\end{array}$ & $\begin{array}{l}0.407 \\
0.358 \\
\end{array}$ & $\begin{array}{l}0.416 \\
0.274\end{array}$ & $\begin{array}{l}0.42 \\
0.305 \\
\end{array}$ & $\begin{array}{l}0.392 \\
0.348\end{array}$ & $\begin{array}{l}0.415 \\
0.361 \\
\end{array}$ & $\begin{array}{l}0.423 \\
0.392 \\
\end{array}$ & & & \\
\hline 9 & Do my extra-class tasks & $\begin{array}{l}0.373 \\
0.303\end{array}$ & $\begin{array}{l}0.365 \\
0.335\end{array}$ & $\begin{array}{l}0.343 \\
0.357\end{array}$ & $\begin{array}{l}0.439 \\
0.349\end{array}$ & $\begin{array}{l}0.343 \\
0.337\end{array}$ & $\begin{array}{l}0.465 \\
0.38\end{array}$ & $\begin{array}{l}0.384 \\
0.335\end{array}$ & $\begin{array}{l}0.405 \\
0.405\end{array}$ & & \\
\hline 10 & $\begin{array}{l}\text { Control the disruptive behavior } \\
\text { of my classmates }\end{array}$ & $\begin{array}{l}0.193 \\
0.179\end{array}$ & $\begin{array}{l}0.218 \\
0.111 \\
\end{array}$ & $\begin{array}{l}0.203 \\
0.148\end{array}$ & $\begin{array}{l}0.245 \\
0.197 \\
\end{array}$ & $\begin{array}{l}0.195 \\
0.166\end{array}$ & $\begin{array}{l}0.252 \\
0.126 \\
\end{array}$ & $\begin{array}{l}0.213 \\
0.194 \\
\end{array}$ & $\begin{array}{l}0.334 \\
0.26\end{array}$ & $\begin{array}{l}0.21 \\
0.187 \\
\end{array}$ & \\
\hline 11 & Prevent behavior problems & $\begin{array}{l}0.308 \\
0.279\end{array}$ & $\begin{array}{l}0.29 \\
0.226\end{array}$ & $\begin{array}{l}0.302 \\
0.225\end{array}$ & $\begin{array}{l}0.333 \\
0.292\end{array}$ & $\begin{array}{l}0.245 \\
0.218\end{array}$ & $\begin{array}{l}0.283 \\
0.219\end{array}$ & $\begin{array}{c}0.269 \\
0.3\end{array}$ & $\begin{array}{l}0.356 \\
0.268\end{array}$ & $\begin{array}{l}0.297 \\
0.184\end{array}$ & $\begin{array}{l}0.578 \\
0.532\end{array}$ \\
\hline 12 & Follow the established rules & $\begin{array}{l}0.275 \\
0.265\end{array}$ & $\begin{array}{l}0.309 \\
0.359\end{array}$ & $\begin{array}{l}0.335 \\
0.367\end{array}$ & $\begin{array}{l}0.475 \\
0.452\end{array}$ & $\begin{array}{l}0.328 \\
0.34\end{array}$ & $\begin{array}{l}0.348 \\
0.321\end{array}$ & $\begin{array}{l}0.324 \\
0.366\end{array}$ & $\begin{array}{l}0.335 \\
0.256\end{array}$ & $\begin{array}{l}0.562 \\
0.395\end{array}$ & $\begin{array}{l}0.26 \\
0.204\end{array}$ \\
\hline
\end{tabular}

$\mathrm{N}=8407\left(\mathrm{~N}_{\text {UNA-CR }}=2682\right.$ and $\left.\mathrm{N}_{\text {UGR-ES }}=5725\right), \mathrm{n}=1424\left(\mathrm{n}_{\text {UNA-CR }}=836\right.$ and $\left.\mathrm{n}_{\text {UGR-ES }}=588\right)$. In all cases $p<0.01$, tests were two-tailed with a 95\% confidence level. * In each case, the data in the upper half of the box corresponds to UNA-CR and the data in the lower half corresponds to UGR-ES.

\section{Discussion and Recommendations}

Both populations of teachers in training have a high self-efficacy in the analyzed variables. The UNA-CR population of teachers in training has high self-efficacy in getting ahead with difficult situations, correctly doing extra-class tasks and exercises proposed in their training even when they are difficult, learning with little support at home, paying attention to the teachers' explanations and instructions and following the established rules. In the UGR-ES population these latter variables also stand out, a high self-efficacy is observed in following the established rules, paying attention to the teachers' explanations and following their instructions. In both populations a good self-efficacy is perceived in these variables, it is recommended to extend the study in order to determine the causes 
of these good results. In this sense, recent research recommends encouraging the development of self-efficacy as an important element in teacher training [41-47].

On the other hand, in both populations it is observed that the lowest results of self-efficacy are in preventing behavioral problems, controlling the disruptive behavior of classmates and motivating oneself when classes are uninteresting. In both populations, the statistical tests indicate the existence of groups not achieving self-efficacy in these variables. In this sense, it is recommended to expand the study of these variables, clearly identify the sectors of the populations not achieving self-efficacy in these capacities and develop strategies to improve the self-efficacy of the teachers in training. Some research offers ideas about the variables that influence self-efficacy and open the possibility of putting into practice strategies for their development in teachers [48-57].

The UNA-CR population shows greater self-efficacy in getting ahead with the difficult situations, learning with little support at home, doing extra-class tasks, controlling disruptive behavior of classmates and preventing behavioral problems, remembering what has been learnt in past lessons and staying motivated when classes are uninteresting. Because these variables refer to important capacities for teachers in training, it is recommended to continue with comparative research to deepen the study of population differences regarding these variables.

It has been proven in the study that the degree program of the teacher in training is a factor influencing self-efficacy in preventing behavioral problems, achieving working with classmates and following the instructions of teachers correctly, in both populations. However, in the UNA-CR population, it also influences the students' confidence in their capacity to keep working on tasks when they are difficult, to overcome the adverse influences of society in learning and to do extra-class tasks.

In the UGR-ES case, the level reached in the degree program affects the self-perceived ability of the population teachers in training to do the exercises correctly, to remember what has been learnt in past lessons and to overcome the adverse influences of society in learning. For this population, doing the exercises correctly is also influenced by having studied at a different university, having completed another degree program, and having obtained the maximum university graduation. These last factors also affect self-efficacy in doing the extra-class tasks and paying attention to the teachers' explanations, in the UGR-ES population. It is recommended to conduct comparative research between degree programs and levels to deepen the understanding of the self-efficacy of teachers in training. In general, it is recommended to take into account all the factors with an impact on the self-efficacy of teachers in training in future studies, this will help to identify causes and formulate improvement proposals. For example, it could deepen the understanding of why and how the availability of a laptop to access the Internet influences $(E S=0.135$ ) the self-efficacy to work with classmates. Research on the subject points out the importance of a positive self-efficacy for the adequate professional performance of a teacher [58-64].

Both teacher populations demonstrate that the self-efficacy to get ahead with the most difficult situations and the self-efficacy to do the exercises correctly are strongly related, also self-efficacy to pay attention to the teachers' explanations is strongly related with the self-efficacy to do the exercises correctly, also, the self-perceived ability to control the disruptive behavior of classmates has a strong relationship with the self-perceived ability to prevent behavior problems. Only in the UNA-CR population does the perception of the student's own ability to do extra-class tasks have a strong relationship with the ability to follow established rules. It is recommended to continue with the investigation of these relationships as a way to improve the understanding of the self-efficacy of teachers in training.

\section{Conclusions}

The conclusions of the present study are the following:

i. In both populations, high levels of self-efficacy are observed during initial training.

ii. In both populations, self-efficacy stands out in following established rules, paying attention to the teachers' explanations and following their instructions. 
iii. The UNA-CR population has significantly greater confidence in their ability to get ahead with the most difficult situations, to achieve learning with little support at home, to do extra-class tasks, to control disruptive behavior of classmates, to prevent behavior problems, to remember what has been learnt in past lessons and to motivate oneself when classes are uninteresting.

iv. The general variables "Degree program" and "Level reached in the degree program" influence the self-efficacy of teachers in training, in this sense, it is recommended to do comparative research between degree programs and levels in them to increase the understanding of this subject. In both university populations, the variable "Degree program" affects the self-perceived ability to prevent behavior problems, successfully work with classmates and follow the instructions of teachers correctly.

v. In both populations the availability of a laptop to access the Internet affects the ability to work with classmates. It is recommended to deepen the understanding of the influence of this device on the self-efficacy of the teachers in training.

vi. The self-efficacy to get ahead with the most difficult situations and the self-efficacy to do the exercises correctly are strongly related. Also, the self-efficacy to pay attention to the teachers' explanations is related with the self-efficacy to do the exercises correctly, and the self-efficacy to control the disruptive behavior of my classmates is related with the self-efficacy to prevent behavioral problems. These are self-efficacy pairs that enhance each other. It is recommended to encourage their development.

Author Contributions: Conceptualization: E.C.-B., T.S.-M., J.-A.M.-M.and M.S.-P. Methodology: E.C.-B. and T.S.-M. Software, E.C.-B. and T.S.-M. Validation, E.C.-B., T.S.-M., J.-A.M.-M.and M.S.-P. Formal analysis: E.C.-B. Investigation: E.C.-B., T.S.-M., J.-A.M.-M. and M.S.-P. Data curation: E.C.-B. and T.S.-M. Writing-original draft preparation: E.C.-B. and T.S.-M. Writing—review and editing: E.C.-B. and M.S.-P.

Funding: This research received no external funding.

Conflicts of Interest: The authors declare no conflict of interest.

\section{Appendix A}

\section{Self-efficacy and self-regulation scale - Students}

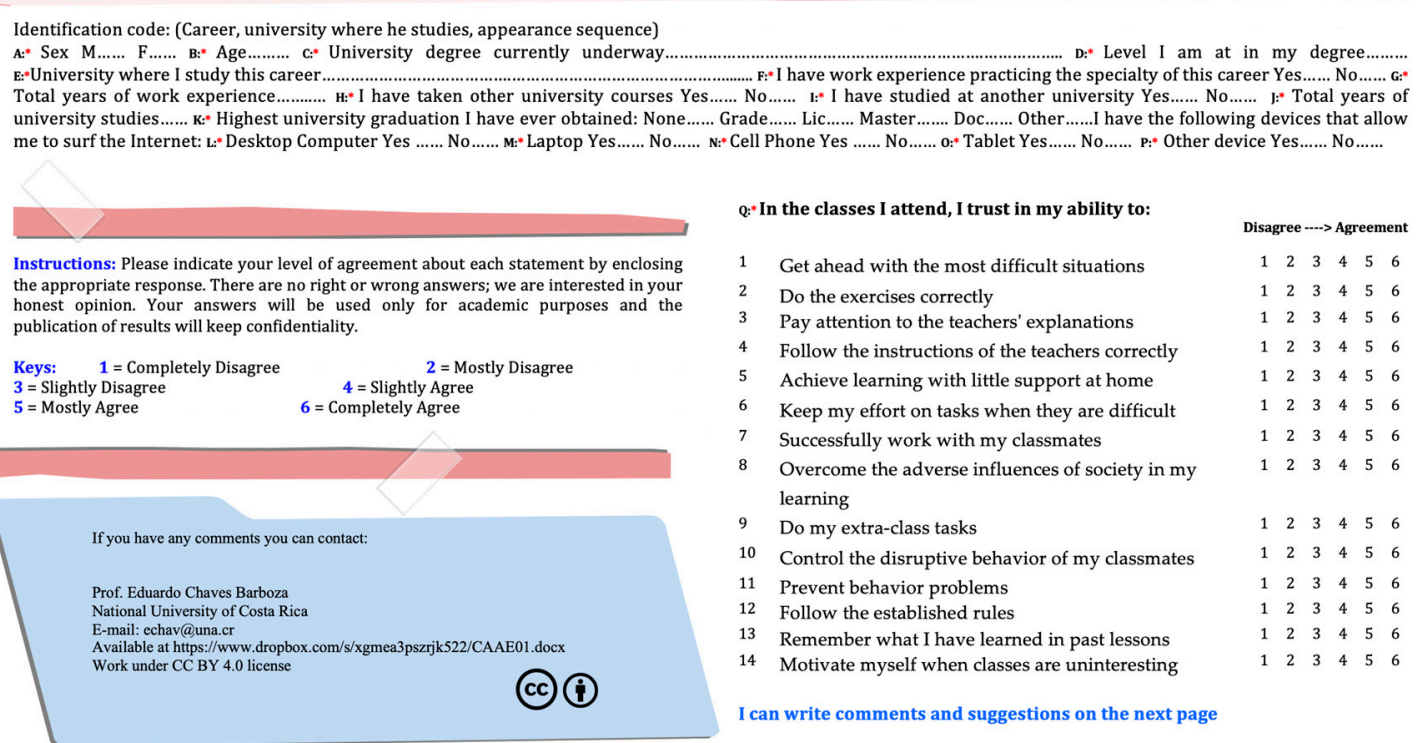

Figure A1. The questionnaire. 


\section{References}

1. Bandura, A. The Exercise of Control; W. H. Freeman: New York, NY, USA, 1997.

2. Bandura, A. Multifaced impact of self-efficacy beliefs on academic functioning. Child Dev. 1996, 67, 1206-1222. [CrossRef] [PubMed]

3. Bandura, A. Self-Efficacy-Toward a unifying theory of behavioral change. Psychol. Rev. 1977, 84, 191-215. [CrossRef] [PubMed]

4. Pannebakker, F.D.; van Genugten, L.; Diekstra, R.F.W.; Gravesteijn, C.; Fekkes, M.; Kuiper, R.; Kocken, P.L. A Social Gradient in the Efects of the Skills for Life Program on Self-Efficacy and Mental Wellbeing of Adolescent Students. J. Sch. Health 2019, 89, 587-595. [CrossRef] [PubMed]

5. Hwang, M.H.; Choi, H.C.; Lee, A.; Culver, J.D.; Hutchison, B. The Relationship between Self-Efficacy and Academic Achievement: A 5-Year Panel Analysis. Asia-Pac. Educ. Res. 2016, 25, 89-98. [CrossRef]

6. Waltz, S.B. Tutor training for service learning: Impact on self-efficacy beliefs. Mentor. Tutor. 2019, $27,26-43$. [CrossRef]

7. Ferreira, P.C.; Simao, A.M.V.; Paiva, A.; Ferreira, A. Responsive bystander behaviour in cyberbullying: A path through self-efficacy. Behav. Inf. Technol. 2019. [CrossRef]

8. Martinez, J.G.; Medina, A.R. Approaches to learning self-regulation and self-efficacy and their influence on academic performance in university students. Eur. J. Investig. Health Psychol. Educ. 2019, 9, 95-107. [CrossRef]

9. Huang, X.X.; Mayer, R.E. Adding Self-Efficacy Features to an Online Statistics Lesson. J. Educ. Comput. Res. 2019, 57, 1003-1037. [CrossRef]

10. Toran, M. Does sense of efficacy predict classroom management skills? An analysis of the pre-school teacher's professional competency. Early Child Dev. Care 2019, 189, 1271-1283. [CrossRef]

11. Ozcan, Z.C.; Gumus, A.E. A modelling study to explain mathematical problem-solving performance through metacognition, self-efficacy, motivation, and anxiety. Aust. J. Educ. 2019, 63, 116-134. [CrossRef]

12. Chao, C.N.G.; Sze, E.C.W.; Forlin, C.; Ho, F.C. Improving teachers' self-efficacy in applying teaching and learning strategies and classroom management to students with special education needs in Hong Kong. Teach. Teach. Educ. 2017, 66, 360-369. [CrossRef]

13. Mahalingappa, L.; Hughes, E.M.; Polat, N. Developing preservice teachers' self-efficacy and knowledge through online experiences with English language learners. Lang. Educ. 2018, 32, 127-146. [CrossRef]

14. Klassen, R.; Chiu, M.M. Effects on Teachers' Self-Efficacy and Job Satisfaction: Teacher Gender, Years of experience, and Job Stress. J. Educ. Psychol. 2010, 102, 741-756. [CrossRef]

15. Goddard, Y.; Kim, M.J. Examining Connections Between Teacher Perceptions of Collaboration, Differentiated Instruction, and Teacher Efficacy; Teachers College Record; Columbia University: New York, NY, USA, 2018; Volume 120.

16. Ulas, O.; Yildirim, I. Influence of locus of control, perceived career barriers, negative affect, and hopelessness on career decision-making self-efficacy among Turkish university students. Int. J. Educ. Vocat. Guid. 2019, 19, 85-109. [CrossRef]

17. Duchatelet, D.; Donche, V. Fostering self-efficacy and self-regulation in higher education: A matter of autonomy support or academic motivation? High. Educ. Res. Dev. 2019, 38, 733-747. [CrossRef]

18. Oerke, B.; McElvany, N.; Ohle-Peters, A.; Horz, H.; Ullrich, M. Attitudes, motivation and self-efficacy of teachers School type-related differences and correlations with teaching behavior when teaching with texts and integrated pictures. Z. Fur Erzieh. 2018, 21, 793-815. [CrossRef]

19. Bjerke, A.H.; Solomon, Y. Developing Self-Efficacy in Teaching Mathematics: Pre-Service Teachers' Perceptions of the Role of Subject Knowledge. Scand. J. Educ. Res. 2019. [CrossRef]

20. De Smul, M.; Heirweg, S.; Van Keer, H.; Devos, G.; Vandevelde, S. How competent do teachers feel instructing self-regulated learning strategies? Development and validation of the teacher self-efficacy scale to implement self-regulated learning. Teach. Teach. Educ. 2018, 71, 214-225. [CrossRef]

21. Eren, A.; Yesilbursa, A. Pre-service teachers' teaching-specific hopes and their motivational forces: The roles of efficacy beliefs and possible selves. Teach. Teach. Educ. 2019, 82, 140-152. [CrossRef]

22. Zhang, J.; Cao, C.; Shen, S.S.; Qian, M. Examining Effects of Self-Efficacy on Research Motivation among Chinese University Teachers: Moderation of Leader Support and Mediation of Goal Orientations. J. Psychol. 2019, 153, 414-435. [CrossRef] 
23. Chaves, E.; Trujillo, J.M.; López, J.A.; Sola, T. Actions and achievements of self-regulated learning in personal environments. J. New Approaches Educ. Res. 2017, 6, 135-143. [CrossRef]

24. Schipper, T.; Goei, S.L.; de Vries, S.; van Veen, K. Developing teachers' self-efficacy and adaptive teaching behaviour through lesson study. Int. J. Educ. Res. 2018, 88, 109-120. [CrossRef]

25. Chizhik, E.W.; Chizhik, A.W.; Close, C.; Gallego, M. Developing student teachers' teaching self-efficacy through Shared Mentoring in Learning Environments (SMILE). Int. J. Mentor. Coach. Educ. 2018, 7, 35-53. [CrossRef]

26. Hutzler, Y.; Meier, S.; Reuker, S.; Zitomer, M. Attitudes and self-efficacy of physical education teachers toward inclusion of children with disabilities: A narrative review of international literature. Phys. Educ. Sport Pedagog. 2019, 24, 249-266. [CrossRef]

27. Poulou, M.S.; Reddy, L.A.; Dudek, C.M. Relation of teacher self-efficacy and classroom practices: A preliminary investigation. Sch. Psychol. Int. 2019, 40, 25-48. [CrossRef]

28. Glackin, M.; Hohenstein, J. Teachers' self-efficacy: Progressing qualitative analysis. Int. J. Res. Method Educ. 2018, 41, 217-290. [CrossRef]

29. Hopman, J.A.B.; Tick, N.T.; van der Ende, J.; Wubbels, T.; Verhulst, F.C.; Maras, A.; Breeman, L.D.; van Lier, P.A.C. Special education teachers' relationships with students and self-efficacy moderate associations between classroom-level disruptive behaviors and emotional exhaustion. Teach. Teach. Educ. 2018, 75, 21-30. [CrossRef]

30. Yada, A.; Tolvanen, A.; Savolainen, H. Teachers' attitudes and self-efficacy on implementing inclusive education in Japan and Finland: A comparative study using multi group structural equation modelling. Teach. Teach. Educ. 2018, 75, 343-355. [CrossRef]

31. An, Y.J. The effects of an online professional development course on teachers' perceptions, attitudes, selfefficacy, and behavioral intentions regarding digital game-based learning. ETRED-Educ. Technol. Res. Dev. 2018, 66, 1505-1527. [CrossRef]

32. Kaygisiz, S.; Anagun, S.S.; Karahan, E. The Predictive Relationship between Self-Efficacy Levels of English Teachers and Language Teaching Methods. Eurasian J. Educ. Res. 2018, 78, 183-202. [CrossRef]

33. Arslan, S.T. Turkish Language and Literature Pre-Service Teachers' Self-Efficacy Beliefs of Educational Internet Use. Pamukkale Univ. Egit. Fak. Derg. Pamukkale Univ. J. Educ. 2018, 44, 77-91. [CrossRef]

34. Ciampa, K.; Gallagher, T.L. A comparative examination of Canadian and American pre-service teachers' efficacy beliefs for literacy instruction. Read. Writ. 2018, 31, 457-481. [CrossRef]

35. Oncu, E. An examination of Turkish physical education teachers' interpersonal self-efficacy beliefs. Phys. Educ. Stud. 2019, 23, 37-44. [CrossRef]

36. Ma, K.; Cavanagh, M. Classroom Ready? Pre-Service Teachers' Self-Efficacy for Their First Professional Experience Placement. Aust. J. Teach. Educ. 2018, 43, 134-151. [CrossRef]

37. Gan, D.; Gal, A. Self-efficacy for promoting EFS among pre-service teachers in Israel. Environ. Educ. Res. 2018, 24, 1062-1075. [CrossRef]

38. Mahasneh, A.M.; Alwan, A.F. The Effect of Project-Based Learning on Student Teacher Self-efficacy and Achievement. Int. J. Instr. 2018, 11, 511-524. [CrossRef]

39. Neto, R.D.A.; Rodrigues, V.P.; Stewart, D.; Xiao, A.N.; Snyder, J. The influence of self-eficacy on entrepreneurial behavior among K-12 teachers. Teach. Teach. Educ. 2018, 72, 44-53. [CrossRef]

40. George, S.V.; Richardson, P.W.; Watt, H.M.G. Early career teachers' self-efficacy: A longitudinal study from Australia. Aust. J. Educ. 2018, 62, 217-233. [CrossRef]

41. Malandrakis, G.; Papadopoulou, P.; Gavrilakis, C.; Mogias, A. An education for sustainable development self-efficacy scale for primary preservice teachers: Construction and validation. J. Environ. Educ. 2019, 50, 23-36. [CrossRef]

42. Hawe, E.; Lightfoot, U.; Dixon, H. First-year students working with exemplars: Promoting self-efficacy, self-monitoring and self-regulation. J. Furth. High. Educ. 2019, 43, 30-44. [CrossRef]

43. Hsiao, C.C. Longitudinal Research on In-Service Trainee Teachers Development of Self-Efficacy for Creative Teaching. J. Res. Educ. Sci. 2017, 62, 25-55. [CrossRef]

44. Kassis, W.; Graf, U.; Keller, R.; Ding, K.; Rohlfs, C. The role of received social support and self-efficacy for the satisfaction of basic psychological needs in teacher education. Eur. J. Teach. Educ. 2019, 42, 391-409. [CrossRef] 
45. Makhalemele, T.; Payne-van Staden, I. Enhancing teachers' self-efficacy within full-service schools: A disregarded aspect by the District-Based Support Team. Int. J. Incl. Educ. 2018, 22, 983-996. [CrossRef]

46. Norris, C.M.; Morris, J.E.; Lummis, G.W. Preservice teachers' self-efficacy to teach primary science based on 'science learner' typology. Int. J. Sci. Educ. 2018, 40, 2292-2308. [CrossRef]

47. Lee, K.W.; Cheung, R.Y.M.; Chen, M. Preservice teachers' self-efficacy in managing students with symptoms of attention deficit/hyperactivity disorder: The roles of diagnostic label and students' gender. Psychol. Sch. 2019, 56, 595-607. [CrossRef]

48. Malinauskas, R.K. Enhancing of Self-Efficacy in Teacher Education Students. Eur. J. Contemp. Educ. 2017, 6, 732-738. [CrossRef]

49. Frumos, L. Attitudes and Self-Efficacy of Romanian Primary School Teachers towards Including Children with Special Educational Needs in Regular Classrooms. Rev. Rom. Pentru Educ. Multidimens. 2018, 10, 118-135. [CrossRef]

50. Guo, Y.; Justice, L.M.; Sawyer, B.; Tompkins, V. Exploring factors related to preschool teachers' self-efficacy. Teach. Teach. Educ. 2011, 27, 961-968. [CrossRef]

51. Burgueno, R.; Sicilia, A.; Medina-Casaubon, J.; Alcaraz-Ibanez, M.; Lirola, M.J. Psychometry of the Teacher's Sense of Efficacy Scale in Spanish Teachers' Education. J. Exp. Educ. 2019, 87, 89-100. [CrossRef]

52. Zee, M.; Koomen, H.M.Y.; de Jong, P.F. How different levels of conceptualization and measurement affect the relationship between teacher self-efficacy and students' academic achievement. Contemp. Educ. Psychol. 2018, 55, 189-200. [CrossRef]

53. Kirbulut, Z.D. Exploring the Relationship between Metavariables and Self-efficacy in Chemistry. Eurasian J. Educ. Res. 2019, 81, 37-55. [CrossRef]

54. Ekici, D.I. Development of pre-service teachers' teaching self-efficacy beliefs through an online community of practice. Asia Pac. Educ. Rev. 2018, 19, 27-40. [CrossRef]

55. von Suchodoletz, A.; Jamil, F.M.; Larsen, R.A.A.A.; Hamre, B.K. Personal and contextual factors associated with growth in preschool teachers' self-efficacy beliefs during a longitudinal professional development study. Teach. Teach. Educ. 2018, 75, 278-289. [CrossRef]

56. Alrajhi, M.; Aldhafri, S.; Alkharusi, H.; Albusaidi, S.; Alkharusi, B.; Ambusaidi, A.; Alhosni, K. The predictive effects of math teachers' emotional intelligence on their self-efficacy perceived beliefs. Teach. Teach. Educ. 2017, 67, 378-388. [CrossRef]

57. Moslemi, N.; Habibi, P. The Relationship among Iranian EFL Teachers' Professional Identity, Skills, Self-efficacy and Critical Thinking Skills. How Colombian J. Engl. 2019, 26, 107-128. [CrossRef]

58. Hoogendijk, C.; Tick, N.T.; Hofman, W.H.A.; Holland, J.G.; Severiens, S.E.; Vuijk, P.; van Veen, A.F.D. Direct and indirect effects of Key2Teach on teachers' sense of self-efficacy and emotion al exhaustion, a randomized controlled trial. Teach. Teach. Educ. 2018, 76, 1-13. [CrossRef]

59. Clark, S.; Newberry, M. Are we building preservice Teacher self-efficacy? A large-scale study examining Teacher education experiences. Asia-Pac. J. Teach. Educ. 2019, 47, 32-47. [CrossRef]

60. Choi, E.; Lee, J. EFL teachers' self-efficacy and teaching practices. ELT J. 2018, 72, 175-186. [CrossRef]

61. Kirbulut, Z.D.; Uzuntiryaki-Kondakci, E. Examining the mediating effect of science self-efficacy on the relationship between metavariables and science achievement. Int. J. Sci. Educ. 2019, 41, 995-1014. [CrossRef]

62. Kanadli, S. Prospective Teachers' Professional Self-Eficacy Beliefs in Terms of Their Perceived Autonomy Support and Attitudes towards the Teaching Profession: A Mixed Methods Study. Educ. Sci. Theory Pr. 2017, 17, 1847-1871. [CrossRef]

63. Burak, S. Self-efficacy of pre-school and primary school pre-service teachers in musical ability and music teaching. Int. J. Music Educ. 2019, 37, 257-271. [CrossRef]

64. Leonardo, F.C.L.; Murgo, C.S.; Sena, B.C.S. The Pedagogical Action and Teacher Self-Efficacy in Higher Education. Eccos-Rev. Cient. 2019, 48, 255-272. [CrossRef]

(C) 2019 by the authors. Licensee MDPI, Basel, Switzerland. This article is an open access article distributed under the terms and conditions of the Creative Commons Attribution (CC BY) license (http://creativecommons.org/licenses/by/4.0/). 